\title{
Millennials' representations regarding cohabitation: a qualitative exploratory study
}

\author{
Mariana Silva ${ }^{1}$, Gonçalo Reis ${ }^{1}$, Catarina Brandão ${ }^{1}$ \\ ${ }^{1}$ Faculty of Psychology and Education Sciences of the University of Porto, Porto, Portugal. mariana96dtms@gmail.com; \\ goncalomanuelreis@gmail.com; catarina@fpce.up.pt
}

Living together without marrying has become a common trend (Carmichael, 1995; Carmichael \& Mason, 1998). Coabitation is increasingly a normative step in relationships, reflecting a short-lived union, which usually lasts two years (Kennedy \& Bumpass, 2008). When the couple reaches the thirdyear cohabitating, the relationship tends to culminate in either dissolution or marriage. Cohabitation is an option particularly for individuals belonging to generation Millennial. Relationships have become far more unstable for Millennials than they were for Baby Boomers or Generation X (Eickmeyer, 2016) and one quarter of Millennials will probably cohabitate, in contrast to only $16 \%$ of the Baby Boomer cohort (Eickmeyer \& Manning, 2018).

The goal of this study is to explore and identify Millennials' representations regarding cohabitation with a romantic partner. We conducted a qualitative exploratory and descriptive research, aiming to explore (1) the challenges that Millennials associate to cohabitation; (2) how Millennials would prepare the process of transitioning to cohabitation; and (3) the strategies they believe to have a positive impact in transitioning to cohabitation.

We gathered data using an online questionnaire answered by individuals belonging to Generation Millennial, in a romantic relationship but not cohabitating, 18 women and 12 men, age ranging from 20 to 27 years. We also conducted an interview with a couple belonging to generation millennial, cohabitating for eight months (at the time of the interview), after dating for four years. Both are 22 years old. Data was analyzed using qualitative thematic analysis following the proposal of Braun and Clarke (2006), using NVivo11 (QSR).

The main challenges anticipated in this study are related to managing the dynamic as a couple; how to reconcile each other's resources; and ways of being. When focusing the process of preparing to transition to cohabitation, participants stress the importance of Planning; Securing several aspects of the relationship; and Communicating. Stayover is also a way of preparing the process (in the form of a training), as well as being empathic regarding the partner. The strategies that once cohabitating should be adopted to guarantee the cohabitation success are Adapting to the partner; Communication; Financial management; Focus on the self; Sharing; and Spending time together.

Results suggest the importance of communication and planning before cohabitation, as well as ensuring space for oneself. Workload, financial management, coping with the routine and housework are seen as challenges. The couple's experience is coherent with many of the representations regarding cohabitation. Social support was absent in the questionnaires data, but is experienced as fundamental by the couple. Knowing what Millennials think regarding cohabitation allows understanding how they approach this new chapter in life.

Keywords: Cohabitation, Transition, Millennials, Exploratory research, Qualitative Thematic Analysis 


\section{References}

Braun, V., \& Clarke, V. (2006). Using thematic analysis in psychology. Qualitative Research in Psychology, 3(2), 77-101. doi:10.1191/1478088706qp063oa.

Carmichael, G. A. (1995). Consensual partnering in the more developed countries. Journal of the Australian Population Association, 12(1), 51-86.

Carmichael, G., \& Mason, C. (1998). Consensual partnering in Australia: A review and 1991 census profile. Journal of the Australian Population Association, 15(2), 131-154.

Eickmeyer, K. (2016). Even More 'Premarital Divorce': Cohabitation and Multiple Union Dissolutions during Young Adulthood. (Electronic Thesis or Dissertation). Retrieved from https://etd.ohiolink.edu/, last accessed 26/05/2018.

Eickmeyer, K. J., \& Manning, W. D. (2018). Serial Cohabitation in Young Adulthood: Baby Boomers to Millennials. Journal of Marriage and Family, 80(4), 826-840.

Kennedy, S., \& Bumpass, L. (2008). Cohabitation and children's living arrangements: New estimates from the United States. Demographic research, 19, 1663-1692. 